\title{
Pseudonocardia dioxanivorans sp. nov., a novel actinomycete that grows on 1,4-dioxane
}

\author{
Shaily Mahendra and Lisa Alvarez-Cohen \\ Department of Civil and Environmental Engineering, University of California, Berkeley, \\ CA 94720-1710, USA
}

Correspondence

Lisa Alvarez-Cohen

alvarez@ce.berkeley.edu

\begin{abstract}
An actinomycete strain $\left(\mathrm{CB} 1190^{\top}\right)$ was previously isolated from industrial sludge contaminated with 1,4-dioxane. The cells of this culture are Gram-positive and exhibit branching aerial and vegetative mycelium. Analysis of the $16 \mathrm{~S}$ rRNA gene sequence indicates that the strain belongs to the genus Pseudonocardia, closely related to Pseudonocardia hydrocarbonoxydans, $P$. sulfidoxydans and $P$. halophobica. Physiological and biochemical characteristics of CB1190 ${ }^{\top}$ are different from those of other known Pseudonocardia species. The novel organism described here is distinguished by its ability to grow on 1,4-dioxane, which is a probable human carcinogen. This culture can also grow on tetrahydrofuran, gasoline aromatics and several other toxic environmental contaminants. Strain $\mathrm{CB}_{1190^{\top}}$ is capable of fixing dinitrogen. The predominant fatty acids are $16: 0$ iso, $16: 1$ iso cis9 and $17: 1$ iso cis9. The major phospholipid fatty acids are $16: 0$ iso, $16: 0$ 10-Me and 17:0 10-Me. The peptidoglycan belongs to type $\mathrm{A} 1 \gamma$, meso-diaminopimelic acid. The major menaquinone is MK-8 $\left(\mathrm{H}_{4}\right)$. Mycolic acids are absent. The $\mathrm{G}+\mathrm{C}$ content is $74 \mathrm{~mol} \%$. Based on morphological, physiological, chemotaxonomic and phylogenetic evidence, it is proposed that strain CB1190 ${ }^{\top}$ (=ATCC $55486^{\top}=$ DSM $44775^{\top}$ ) be classified as the type strain of a novel species, Pseudonocardia dioxanivorans sp. nov. Further studies with this organism will provide insights into metabolic pathways, responsible enzymes, kinetics and the fate of 1,4-dioxane in the environment.
\end{abstract}

Degradation of toxic pollutants by micro-organisms has emerged as a promising remediation strategy for groundwater contaminants. Actinomycetes have been shown to specifically degrade hydrocarbons (McCarthy \& Williams, 1992), chlorinated solvents (Wackett et al., 1989), explosives (Pasti-Grigsby et al., 1996), plasticizers (Klausmeier \& Osman, 1976) and azo dyes (Zhou \& Zimmermann, 1993). Within the actinomycetes, members of the genus Pseudonocardia (Henssen, 1957; Huang et al., 2002) have been reported to use hydrocarbons (Juteau et al., 1999; Lechevalier et al., 1986; Lee et al., 2004), methyl sulfides (Reichert et al., 1998) and tetrahydrofuran (THF) (Kohlweyer et al., 2000) as growth substrates.

In this paper, we describe a novel Pseudonocardia species that is the only known pure culture that can grow on 1,4-dioxane, a toxic groundwater pollutant (Parales et al., 1994). This culture can be used for bioaugmentation at

Abbreviations: FAME, fatty acid methyl ester; PLFA, phospholipid fatty acid; THF, tetrahydrofuran.

The GenBank/EMBL/DDBJ accession number for the 16S rRNA gene sequence of Pseudonocardia dioxanivorans $\mathrm{CB} 1190^{\top}$ is $\mathrm{AY} 340622$.

A scanning electron micrograph of cells of strain $\mathrm{CB} 1190^{\top}$ and details of fatty acid compositions are available as supplementary material in IJSEM Online. 1,4-dioxane- and THF-contaminated sites. 1,4-Dioxane is widely used as a stabilizer for chlorinated compounds and as a solvent in the manufacture of textiles, organic chemicals, fumigants, automotive coolants and hygiene products (Mohr, 2001). 1,4-Dioxane is a probable human carcinogen and a priority pollutant that has been detected in surface and ground waters (Mohr, 2001).

The culture CB1190 was graciously supplied by Dr Rebecca Parales, University of California, Davis. It was originally enriched by Parales and co-workers from 1,4-dioxanecontaminated industrial sludge from Darlington, SC, USA (Parales et al., 1994). The initial enrichments were performed in basal salts medium with $1 \cdot 5-4 \cdot 0 \mathrm{mM}$ THF in the presence of $0 \cdot 1 \%(\mathrm{w} / \mathrm{v})$ yeast extract. Enrichments capable of degrading both 1,4-dioxane and THF were selected. The mixed enrichment degraded up to $10 \mathrm{mM}$ 1,4-dioxane per day. Only one prokaryotic isolate, designated strain $\mathrm{CB} 1190^{\mathrm{T}}$, was capable of growing on $1,4-$ dioxane as sole carbon source.

In our laboratory, $\mathrm{CB} 1190^{\mathrm{T}}$ was grown aerobically in ammonium mineral salts (AMS) liquid medium (Parales et al., 1994) at $30^{\circ} \mathrm{C}$ with $5 \mathrm{mM} \mathrm{1,4-dioxane.} \mathrm{Cell} \mathrm{biomass}$ was quantified as total protein concentration (Lontoh \& Semrau, 1998). BSA was used as a standard for the Coomassie Plus protein assay kit (Pierce). Cells of strain 
$\mathrm{CB} 1190^{\mathrm{T}}$ were also maintained on plates containing AMS and $1.5 \%$ Bacto agar. The plates were incubated at $30^{\circ} \mathrm{C}$ in a desiccator in which 1,4-dioxane was supplied in the vapour phase by placing a glass microfibre filter (Whatman) in the bottom half of a glass Petri dish placed on the floor of the desiccator. An aliquot of $250 \mu 1$ 1,4-dioxane that had been filter-sterilized $(0 \cdot 1 \mu \mathrm{m}$ pore size $)$ was added to the filter. Every 4-5 days, the filters were replaced with new dioxane-laden filters in the fume hood. The colours and shapes of colonies were recorded weekly. A Hitachi model S-5000 microscope was used for scanning electron microscopy of gold-coated, dehydrated cells. Fourteen-day-old cultures on AMS-agar plates were visualized by electron microscopy.

The ability of $\mathrm{CB} 1190^{\mathrm{T}}$ and reference strains Pseudonocardia hydrocarbonoxydans DSM $43281^{\mathrm{T}}$ and Pseudonocardia sulfidoxydans DSM $44248^{\mathrm{T}}$ to grow aerobically on a variety of carbon sources was investigated using GP2 and SFP2 microplates (Biolog). Cells were grown at $30^{\circ} \mathrm{C}$ on Biolog universal growth agar amended with $0 \cdot 25 \%$ glucose. The $\mathrm{OD}_{590}$ of the inoculum was adjusted to $0 \cdot 2$ before loading $150 \mu \mathrm{l}$ into each well. Similarly, the utilization of various nitrogen sources was tested using the Biolog PM3 microplate. For PM3 plates, the $\mathrm{OD}_{590}$ of the inoculum was adjusted to $0 \cdot 4$ before loading $100 \mu \mathrm{l}$ into each well. The wells were analysed using the Omnilog system after incubating the plates for 7 days at $30^{\circ} \mathrm{C}$. In addition, the capability of $P$. sulfidoxydans and $P$. hydrocarbonoxydans to grow on THF and 1,4-dioxane was tested. The ability of $\mathrm{CB} 1190^{\mathrm{T}}$ to grow on 1,4-dioxane $(99.8 \%$ pure; Aldrich Chemical) and Luria-Bertani (LB) broth (Becton Dickinson) under anaerobic conditions was investigated. The temperature range for growth was examined. Standard phenotypic tests commonly used for describing novel species of actinomycetes were performed (Gordon et al., 1974). The cells were grown in AMS medium with 1,4dioxane added as the sole carbon source and incubated at $30{ }^{\circ} \mathrm{C}$ for up to 28 days. The $\mathrm{pH}$ of AMS medium was adjusted to $7 \cdot 0$ for examining acid production from various carbohydrates, which were added to the AMS medium to achieve $1 \%(\mathrm{w} / \mathrm{v})$ aqueous concentration.

For monitoring growth on 1,4-dioxane, liquid samples were collected at various intervals and filtered with $0.45 \mu \mathrm{m}$ syringe filters to eliminate cells. Dioxane disappearance was measured by injecting $5 \mu \mathrm{l}$ filtered liquid samples into a Varian 3400 gas chromatograph equipped with a flameionization detector (FID) and a GraphPac-GB column (Alltech). The injector, oven and detector temperatures were respectively set at 220,150 and $250^{\circ} \mathrm{C}$. Cell growth was determined by measuring total protein and enzymic activities of soluble monooxgenases were assayed as described by Brusseau et al. (1990). Briefly, duplicate 5-ml aliquots of $\mathrm{CB} 1190^{\mathrm{T}}$ cell suspensions were transferred to $20 \mathrm{ml}$ glass serum vials containing approximately $5 \mathrm{mg}$ crystalline naphthalene. The vials were sealed with Teflonlined rubber septa and incubated at $30^{\circ} \mathrm{C}$ on a platform shaker for $15 \mathrm{~min}$. Fifty microlitres of freshly prepared $5 \mathrm{mg}$ tetrazotized $o$-dianisidine $\mathrm{ml}^{-1}$ were added to the samples. Naphthalene was oxidized to a mixture of 1-naphthol and 2-naphthol by the monooxygenase. The naphthols were detected colorimetrically by reaction with tetrazotized $o$ dianisidine to form purple diazo dyes.

The capability of strains to fix dinitrogen was tested by the activity of nitrogenase, which converts acetylene into ethylene in the presence of an external energy source (Chu \& Alvarez-Cohen, 1996). Briefly, $1 \mathrm{ml}$ acetylene and $20 \mathrm{mM}$ glucose were added to $5 \mathrm{ml}$ cell culture in nitrogen-free AMS medium. The vials were incubated at $30{ }^{\circ} \mathrm{C}$ on a shaker at 150 r.p.m. The headspace concentrations of acetylene and ethylene were analysed by an HP 5890 series II gas chromatograph equipped with an FID. Acetylene-free controls were used to determine background ethylene production. Stoichiometric decrease in acetylene concentration with concomitant production of ethylene was indicative of nitrogenase activity. Ammonia produced by nitrogen-fixing cells was assayed using the Nessler method (Hach method 8038). The colour produced by the reaction of Nessler reagent and ammonium ions was measured at $425 \mathrm{~nm}$ using a Hach DR/2500 spectrophotometer. Uninoculated N-free AMS medium was used as a blank for the colorimetric assay.

Whole-cell fatty acid methyl ester (FAME) analysis was performed by Microchek, Inc. (Northfield, VT, USA) using gas chromatography. The cells were grown at $30{ }^{\circ} \mathrm{C}$ on $\mathrm{BBL}$ trypticase soy broth (BD Diagnostic Systems) for 7 days prior to FAME analysis. Phospholipid fatty acid (PLFA) analysis was performed on 14-day-old cultures grown in AMS and $5 \mathrm{mM} \mathrm{1,4-dioxane} \mathrm{at} 30^{\circ} \mathrm{C}$. The cells were saponified, methylated, solvent-extracted and analysed by GC-MS by using the modified Bligh/Dyer method (White \& Ringelberg, 1998). Analysis of quinones and mycolic acids was carried out by the Deutsche Sammlung von Mikroorganismen und Zellkulturen GmbH (DSMZ), Braunschweig, Germany. The diagnostic diamino acid was determined by analysis of a whole-cell hydrolysate by TLC on cellulose (Hasegawa et al., 1983; Rhuland et al., 1955). Gram staining was performed according to the standard method (Gerhardt et al., 1994).

Genomic DNA was extracted from $\mathrm{CB} 1190^{\mathrm{T}}$ by a two-step enzymic treatment followed by bead-beating lysis and organic extraction (Dojka et al., 1998). PCR amplification of the 16S rRNA gene using bacterial primers $8 \mathrm{~F}\left(5^{\prime}-\right.$ AGAGTTTGATCCTGCCTCAG-3'), 338F (5'-CCTACGGGAGGCAGCAG-3') and 1492R (5'GGYTACCTTGTTACGACTT- $3^{\prime}$ ) was carried out as described by Richardson et al. (2002). Purified PCR products were directly sequenced using an Applied Biosystems 3100 Genetic Analyzer at the University of California Berkeley Sequencing Facility. The partial sequences were aligned using the Autoassembler program version 2.1 (PE Biosystems). CHECK_CHIMERA software (http://rdp.cme.msu.edu/) was used to confirm that the sequences were not of chimeric origin. The $16 \mathrm{~S}$ 
rRNA gene sequences were compared with those in the GenBank database using the BLAST program (http:// www.ncbi.nlm.nih.gov/blast). Detailed phylogenetic analyses were carried out using the ARB program (http:// www.arb-home.de). Evolutionary distance dendrograms were constructed using the Felsenstein substitution model and neighbour-joining tree-building algorithm. Since all input sequences were longer than $1250 \mathrm{bp}$, the parsimony tool was not used. Statistical support for branch points in the dendrograms was estimated by bootstrap resampling analysis of 1000 independent trees (Felsenstein, 1985) using PAUP 4.0 program.

DNA base composition ( $\mathrm{G}+\mathrm{C}$ mol\%) was determined by the DSMZ by HPLC analysis using DNA isolated from $\mathrm{CB} 1190^{\mathrm{T}}$ as described above.

Strain CB1 $190^{\mathrm{T}}$ grows slowly on AMS medium containing 1,4-dioxane. It also grows slowly on rich media such as LB, TSA and R2A in the absence of 1,4-dioxane. When grown in liquid medium, the cells appear as powdery white colonies floating on the liquid surface and form biofilms on the insides and the bottom of the flask. The cells produce white aerial mycelium and yellowish substrate mycelium, which branch and fragment into rod-shaped, non-motile units. No diffusible pigments or sporangia are produced. Hyphal swelling and budding are sometimes observed with this culture. The cells are 1-3 $\mu \mathrm{m}$ in size (a scanning electron micrograph is available as supplementary material in IJSEM Online).

$\mathrm{CB} 1190^{\mathrm{T}}$ is an aerobic micro-organism capable of utilizing 1,4-dioxane as its sole source of carbon and energy for growth. In batch experiments, cell yield was $0 \cdot 09 \pm 0.002 \mathrm{~g}$ protein (g dioxane $)^{-1}$. The observed maximum growth rate was $90 \mu \mathrm{g} \mathrm{l}^{-1} \mathrm{~h}^{-1}$ and the maximum dioxane degradation rate was $0 \cdot 1 \mu \mathrm{g}$ dioxane $(\mu \mathrm{g} \text { protein })^{-1} \mathrm{~h}^{-1}$, and is described by Monod kinetics. The addition of $10 \mathrm{mg}$ vitamins stock $1^{-1}$ (Tanner, 1997) to the AMS medium did not significantly affect the growth rate. $\mathrm{CB} 1190^{\mathrm{T}}$ was capable of growing aerobically on benzene, toluene, formate, Casamino acids, LB broth and trypticase soy broth. No growth was observed on methyl tert-butyl ether or tertbutyl alcohol. While P. sulfidoxydans was able to use THF as a sole growth substrate but not 1,4-dioxane, $P$. hydrocarbonoxydans was unable to grow on either compound. The substrates in Biolog GP2 and SFP2 microplates metabolized by $\mathrm{CB} 1190^{\mathrm{T}}, P$. hydrocarbonoxydans and $P$. sulfidoxydans are listed in Table 1.

Strain $\mathrm{CB} 1190^{\mathrm{T}}$ is capable of utilizing a variety of nitrogen sources, including $\mathrm{NH}_{4}^{+}, \mathrm{NO}_{3}^{-}$and $\mathrm{N}_{2}$. The capability of $\mathrm{CB} 1190^{\mathrm{T}}$ to fix atmospheric nitrogen was indicated by (i) slow but positive growth in ammonium-free AMS medium, as well as in the negative control well of the Biolog PM3 plate, (ii) production of ammonium ions in cell cultures grown in ammonium-free AMS medium and (iii) the presence of nitrogenase activity as measured by stoichiometric reduction of acetylene to ethene. The measured rate of ethylene production was $18 \mathrm{nmol} \mathrm{h}^{-1}(\mathrm{mg} \text { protein })^{-1}$. Abiotic loss of acetylene was negligible. No cell growth or ammonia production was observed in control vials containing $\mathrm{N}$-free medium with headspace containing argon and $5 \%$ oxygen. Neither $P$. hydrocarbonoxydans nor $P$. sulfidoxydans was able to grow in nitrogen-free medium in the presence of glucose or lactate as carbon source. Neither strain was capable of using $\mathrm{N}_{2}$ as a nitrogen source in the Biolog PM3 microplate test. Both strains were unable to reduce acetylene to ethylene, indicating the absence of nitrogenase activity. No other Pseudonocardia species has been reported to fix dinitrogen.

Growth on 1,4-dioxane in AMS was tested at temperatures ranging from 10 to $45^{\circ} \mathrm{C}$, and the optimum growth temperature was found to be $30^{\circ} \mathrm{C}$, with no observed growth at temperatures higher than $37^{\circ} \mathrm{C}$. $\mathrm{CB} 1190^{\mathrm{T}}$ grown on $1,4^{-}$ dioxane was able to oxidize naphthalene to a mixture of 1-naphthol and 2-naphthol, indicating soluble monooxygenase activity. A comparison of physiological properties of $\mathrm{CB} 1190^{\mathrm{T}}$ with $P$. hydrocarbonoxydans and $P$. sulfidoxydans is presented in Table 1 .

The whole-cell fatty acid pattern of $\mathrm{CB} 1190^{\mathrm{T}}$ was of the iso-/anteiso-branched type. The dominant fatty acid was hexadecanoate (details available as supplementary material in IJSEM Online). Saturated, unsaturated and 10-methylbranched fatty acids were also present. These signatures are diagnostic for members of the family Pseudonocardiaceae (Embley et al., 1988; Kroppenstedt, 1992). Ninety-nine per cent of the total peaks were named. The major PLFAs are hexadecanoate $(27 \cdot 5 \%), 10$-methylhexadecanoate $(9 \cdot 3 \%)$ and 10-methylheptadecanoate $(23 \cdot 6 \%)$. Methyl branching on the tenth carbon atom in a fatty acid molecule is specific for many mycolateless nocardioform actinomycetes. Like all other Pseudonocardia species, $\mathrm{CB} 1190^{\mathrm{T}}$ does not synthesize mycolic acids. The dominant menaquinone was MK$8\left(\mathrm{H}_{4}\right)$. In addition, a small amount of MK- $7\left(\mathrm{H}_{4}\right)$ was also present. The cell-wall peptidoglycan of strain $\mathrm{CB} 1190^{\mathrm{T}}$ contained meso-diaminopimelic acid $(m$-Dpm). This indicates Al $\gamma$ peptidoglycan type, which is commonly found in representatives of Pseudonocardia.

The almost complete sequence of the 16S rRNA gene (1422 bp) was used for phylogenetic analyses. Preliminary phylogenetic placements based on the results of BLAST analyses revealed that strain $\mathrm{CB} 1190^{\mathrm{T}}$ is closely related to the members of the family Pseudonocardiaceae. The closest phylogenetic neighbours with validly published names are P. sulfidoxydans (1401/1423 bp) and P. hydrocarbonoxydans $(1400 / 1423 \mathrm{bp})$. Rigorous analysis of the phylogenetic position was carried out by constructing phylogenetic trees using 23 species containing 1353 nucleotides (Fig. 1). Kimura two-parameter neighbour-joining (Saitou \& Nei, 1987) and maximum-likelihood (Felsenstein, 1981) methods were employed. Both methods consistently placed CB1190 ${ }^{\mathrm{T}}$ in the cluster encompassing members of Pseudonocardia with high bootstrap support. This phylogenetic placement was not affected by the choice of different outgroups. The 


\section{Table 1. Physiological characteristics of strain $\mathrm{CB} 1190^{\top}$ and reference Pseudonocardia strains}

Strains: 1, CB1 $190^{\mathrm{T}}$; 2, P. hydrocarbonoxydans DSM 43281 ; 3, P. sulfidoxydans DSM 44248 ${ }^{\mathrm{T}}$. +, Positive or present; W, weakly positive; -, negative or absent. All strains were able to metabolize the following substrates in the Biolog GP2 and SFP2 microplates: dextrin, $\alpha$-Dglucose, maltose, maltotriose, D-mannose, D-trehalose, turanose, acetic acid, L-lactic acid, pyruvic acid methyl ester, pyruvic acid, glycerol, adenosine, $2^{\prime}$-deoxyadenosine, inosine, uridine and DL- $\alpha$-glycerol phosphate. The following compounds were not utilized in the Biolog plate: $\alpha$-cyclodextrin, inulin, Tween $80, N$-acetyl-D-glucosamine, $N$-acetyl- $\beta$-D-mannosamine, L-arabinose, D-arabitol, D-galacturonic acid, methyl $\beta$-Dgalactoside, sedoheptulosan, D-sorbitol, stachyose, D-tagatose, $\alpha$-, $\beta$ - and $\gamma$-hydroxybutyric acid, D-lactic acid methyl ester and L-pyroglutamic acid. All strains were able to utilize the following nitrogen sources: ammonia, nitrite, nitrate, urea, L-alanine, L-aspartic acid, L-phenylalanine, D-aspartic acid, methylamine, ethylamine and uric acid. None of the strains could utilize the following compounds as nitrogen sources: biuret, $N$-phthaloyl-L-glutamic acid, histamine, $\beta$-phenylethylamine, tyramine, D-mannosamine, $N$-acetyl-D-mannosamine, DL- $\alpha$-amino- $N$-butyric acid, $\gamma$-amino- $N$-butyric acid, $\varepsilon$-amino- $N$-caproic acid, DL- $\alpha$-aminocaprylic acid, D-amino- $N$-valeric acid and 2 -amino- $N$-valeric acid.

\begin{tabular}{|c|c|c|c|c|c|c|c|}
\hline Characteristic & 1 & 2 & 3 & Characteristic & 1 & 2 & 3 \\
\hline Carbon sources: & & & & Nitrogen sources: & & & \\
\hline 1,4-Dioxane & + & - & - & Dinitrogen & + & - & - \\
\hline Tetrahydrofuran & + & - & + & L-Arginine & - & - & + \\
\hline Glycogen & - & - & + & L-Asparagine & - & - & + \\
\hline Amygdalin & $\mathrm{w}$ & - & + & L-Cysteine & $\mathrm{w}$ & + & - \\
\hline Arbutin & + & - & + & L-Glutamic acid & + & - & + \\
\hline D-Cellobiose & + & - & - & L-Glutamine & + & - & - \\
\hline D-Fructose & + & + & $\mathrm{w}$ & Glycine & + & + & - \\
\hline D-Galactose & + & - & - & L-Histidine & - & + & + \\
\hline Gentiobiose & + & - & - & L-Isoleucine & - & - & w \\
\hline D-Gluconic acid & + & - & - & L-Leucine & - & - & + \\
\hline m-Inositol & - & - & + & L-Lysine & - & + & + \\
\hline$\alpha$-D-Lactose & - & + & + & L-Methionine & + & - & + \\
\hline Lactulose & - & + & - & L-Proline & - & + & - \\
\hline D-Mannitol & + & $\mathrm{w}$ & - & L-Serine & - & + & + \\
\hline D-Melezitose & + & + & - & L-Threonine & + & + & - \\
\hline D-Melibiose & - & - & + & L-Tryptophan & - & + & + \\
\hline 3-Methyl glucose & - & + & $\mathrm{w}$ & L-Tyrosine & $\mathrm{w}$ & + & - \\
\hline Methyl $\alpha$-D-glucoside & + & - & + & L-Valine & + & - & - \\
\hline Methyl $\beta$-D-glucoside & + & - & + & L-Citrulline & + & - & - \\
\hline Methyl $\alpha$-D-mannoside & - & - & + & L-Homoserine & - & + & - \\
\hline Palatinose & + & - & - & L-Ornithine & - & + & - \\
\hline D-Psicose & + & + & - & Hydroxylamine & + & + & - \\
\hline D-Raffinose & - & $\mathrm{w}$ & - & Ethanolamine & - & + & + \\
\hline L-Rhamnose & + & - & - & Ethylenediamine & + & - & + \\
\hline D-Ribose & + & + & - & Putrescine & + & + & - \\
\hline Salicin & $\mathrm{w}$ & - & + & Acetamide & - & + & + \\
\hline Sucrose & - & + & + & Formamide & - & + & + \\
\hline Xylitol & + & - & - & Xanthine & + & - & w \\
\hline D-Xylose & + & $\mathrm{W}$ & + & Xanthosine & + & - & + \\
\hline$\alpha$-Ketoglutaric acid & - & + & - & Uridine & - & $\mathrm{W}$ & + \\
\hline$\alpha$-Ketovaleric acid & - & + & + & Alloxan & + & + & - \\
\hline Lactamide & $\mathrm{w}$ & - & + & Allantoin & - & + & + \\
\hline D-Malic acid & + & - & - & Parabanic acid & - & - & + \\
\hline L-Malic acid & + & - & - & Decomposition of: & & & \\
\hline Succinamic acid & - & + & + & Adenine & - & $\mathrm{W}$ & - \\
\hline Succinic acid & + & - & + & L-Tyrosine & - & + & + \\
\hline L-Alaninamide & + & - & $\mathrm{W}$ & Xanthine & + & - & + \\
\hline D-Alanine & - & + & + & Hypoxanthine & + & - & + \\
\hline L-Alanine & - & + & + & Growth on: & & & \\
\hline L-Asparagine & - & + & + & $3 \% \mathrm{NaCl}$ & + & - & + \\
\hline L-Glutamic acid & - & - & + & $4 \% \mathrm{NaCl}$ & + & - & - \\
\hline L-Serine & - & + & - & $5 \% \mathrm{NaCl}$ & $\mathrm{w}$ & - & - \\
\hline Putrescine & + & + & - & & & & \\
\hline Thymidine & - & + & + & & & & \\
\hline
\end{tabular}




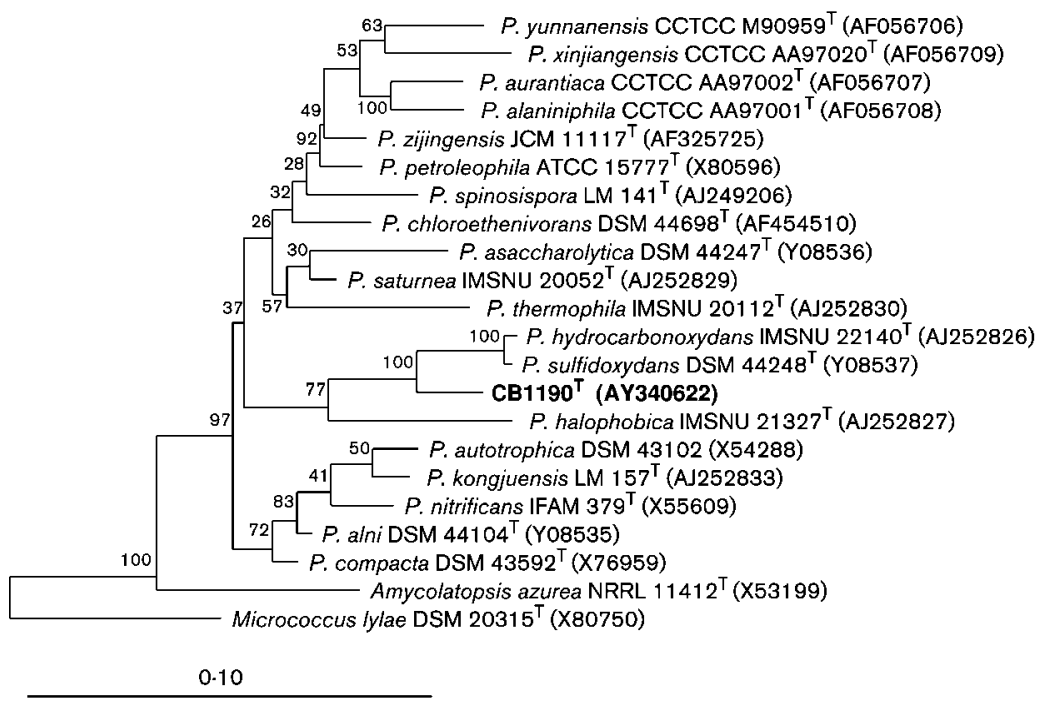

Fig. 1. Evolutionary distance dendrogram displaying the phylogenetic position of Pseudonocardia dioxanivorans sp. nov. CB $1190^{\top}$ obtained by comparative analysis of $16 \mathrm{~S}$ rRNA gene sequence data. The tree is based on 1353 unambiguous nucleotide positions present in all sequences. Bootstrap percentages based on 1000 resamplings are listed at nodes. The scale bar represents $0 \cdot 1$ changes per nucleotide.

bootstrap confidence for the clade containing $\mathrm{CB} 1190^{\mathrm{T}}, P$. sulfidoxydans and P. hydrocarbonoxydans was $100 \%$.

The analysis of genotypic and phenotypic data suggests that $\mathrm{CB} 1190^{\mathrm{T}}$ merits recognition as a novel species in the genus Pseudonocardia. CB1190 ${ }^{\mathrm{T}}$ exhibits $91 \%$ 16S rRNA gene sequence similarity to the type species Pseudonocardia thermophila (Embley et al., 1988) and $98.4 \%$ sequence similarity to its closest neighbours, $P$. sulfidoxydans (Reichert et al., 1998) and P. hydrocarbonoxydans (Lechevalier et al., 1986; Warwick et al., 1994). Moreover, strain $\mathrm{CB} 1190^{\mathrm{T}}$ is unique among Pseudonocardia species in its ability to metabolize 1,4-dioxane and to fix dinitrogen. It is proposed that the organism be classified as Pseudonocardia dioxanivorans sp. nov.

\section{Note added in proof}

Since this article was submitted for publication, a novel species, Pseudonocardia benzenivorans, has been described (Kämpfer \& Kroppenstedt, 2004).

\section{Description of Pseudonocardia dioxanivorans sp. nov.}

Pseudonocardia dioxanivorans (di.ox.a.ni.vo'rans. N.L. n. dioxanum 1,4-dioxane; L. part. adj. vorans devouring; N.L. part. adj. dioxanivorans dioxane-devouring).

The species description is based on the results of this study and Parales et al. (1994). Gram-positive, strictly aerobic, mycolateless actinomycete. Both aerial and vegetative mycelium fragment into rod-shaped elements. Capable of growing on 1,4-dioxane, THF, tetrahydropyran, 1,3dioxane, 2-methyl-1,3-dioxolane, diethyl ether and butyl methyl ether. A variety of other organic compounds, such as ethers, alcohols, carbohydrates, carboxylic acids and amino acids, are also utilized (Table 1). Aerobic autotrophic growth occurs on $\mathrm{H}_{2}$ and $\mathrm{CO}_{2}$. This organism is able to fix dinitrogen. Acid is produced from (+)-D-glucose,
(-)-L-rhamnose, (+)-D-xylose, (-)-D-fructose, (-)-Dtrehalose, cellobiose, $(-)$-D-mannitol, maltose and salicin. Xanthine and hypoxanthine are decomposed. (-)-LTyrosine and adenine are not degraded. Optimal growth temperature is $30^{\circ} \mathrm{C}$. Nitrogenase-positive and oxygenasepositive. Predominant fatty acids are 16:0 iso, 16:1 iso cis 9 and $17: 1$ iso cis9. The major menaquinone $\left[\mathrm{MK}-8\left(\mathrm{H}_{4}\right)\right]$ has eight isoprene units, two of which are hydrogenated. Cell wall contains meso-Dpm. The G+C content is $74 \mathrm{~mol} \%$.

The type strain, $\mathrm{CB} 1190^{\mathrm{T}}\left(=\mathrm{ATCC} 55486^{\mathrm{T}}=\mathrm{DSM} 44775^{\mathrm{T}}\right.$ ), was isolated from a 1,4-dioxane-contaminated sludge sample collected at Darlington, SC, USA (Parales et al., 1994).

\section{Acknowledgements}

We thank Dr Rebecca Parales for providing strain CB1190. Thanks are due to Dr Sharon Borglin for her help with PLFA analysis, Dr Gordon Vrdoljak for his help in scanning electron microscopy and Dr Philip Hugenholtz for his help with phylogenetic analysis. This research was supported by University of California Toxic Substances Research and Teaching Program and by NIEHS Superfund project ES04705.

\section{References}

Brusseau, G. A., Tsien, H. C., Hanson, R. S. \& Wackett, L. P. (1990). Optimization of trichloroethylene oxidation by methanotrophs and the use of a colorimetric assay to detect soluble methane monooxygenase activity. Biodegradation 1, 19-29.

Chu, K. H. \& Alvarez-Cohen, L. (1996). TCE degradation by methane oxidizing cultures grown with various nitrogen sources. Water Environ Res 68, 76-82.

Dojka, M. A., Hugenholtz, P., Haack, S. K. \& Pace, N. R. (1998). Microbial diversity in a hydrocarbon- and chlorinated-solventcontaminated aquifer undergoing intrinsic bioremediation. Appl Environ Microbiol 64, 3869-3877.

Embley, T. M., Smida, J. \& Stackebrandt, E. (1988). The phylogeny of mycolate-less wall chemotype IV actinomycetes and the description of Pseudonocardiaceae fam. nov. Syst Appl Microbiol 11, 44-52. 
Felsenstein, J. (1981). Evolutionary trees from DNA sequences: a maximum likelihood approach. J Mol Evol 17, 368-376.

Felsenstein, J. (1985). Confidence limits on phylogenies: an approach using the bootstrap. Evolution 39, 783-791.

Gerhardt, P., Murray, R. G. E., Wood, W. A. \& Kreig, N. R. (editors) (1994). Methods for General and Molecular Bacteriology. Washington, DC: American Society for Microbiology.

Gordon, R. E., Barnett, D. A., Handerhan, J. E. \& Pang, C. H.-N. (1974). Nocardia coeliaca, Nocardia autotrophica, and the nocardin strain. Int J Syst Bacteriol 24, 54-63.

Hasegawa, T., Takizawa, M. \& Tanida, S. (1983). A rapid analysis for chemical grouping of aerobic actinomycetes. J Gen Appl Microbiol 29, 319-322.

Henssen, A. (1957). Beitrage zur Morphologie und Systematik ter thermophilen Actinomyceten. Arch Mikrobiol 26, 373-414 (in German).

Huang, Y., Wang, L., Lu, Z., Hong, L., Liu, Z., Tan, G. Y. \& Goodfellow, M. (2002). Proposal to combine the genera Actinobispora and Pseudonocardia in an emended genus Pseudonocardia, and description of Pseudonocardia zijingensis sp. nov. Int J Syst Evol Microbiol 52, 977-982.

Juteau, P., Larocque, R., Rho, D. \& LeDuy, A. (1999). Analysis of the relative abundance of different types of bacteria capable of toluene degradation in a compost biofilter. Appl Microbiol Biotechnol 52, 863-868

Kampfer, P. \& Kroppenstedt, R. M. (2004). Pseudonocardia benzenivorans sp. nov. Int J Syst Evol Microbiol 54, 749-751.

Klausmeier, R. E. \& Osman, J. L. (1976). Biodegradation of plastics by actinomycetes. In Proceedings of the Third International Biodegradation Symposium, pp. 815-818. Edited by J. M. Sharpley \& A. P. Kaplan. London: Applied Science Publishers.

Kohlweyer, U., Thiemer, B., Schrader, T. \& Andreesen, J. R. (2000). Tetrahydrofuran degradation by a newly isolated culture of Pseudonocardia sp. strain K1. FEMS Microbiol Lett 186, 301-306.

Kroppenstedt, R. M. (1992). The genus Nocardiopsis. In The Prokaryotes, 2nd edn, pp. 1139-1156. Edited by A. Balows, H. G. Trüper, M. Dworkin, W. Harder \& K. H. Schleifer. Heidelberg: Springer.

Lechevalier, M. P., Prauser, H., Labeda, D. P. \& Ruan, J.-S. (1986). Two new genera of nocardioform actinomycetes: Amycolata gen. nov. and Amycolatopsis gen. nov. Int J Syst Bacteriol 36, 29-37.

Lee, S.-B., Strand, S. E., Stensel, H. D. \& Herwig, R. P. (2004). Pseudonocardia chloroethenivorans sp. nov., a chloroethene degrading actinomycete. Int J Syst Evol Microbiol 54, 131-139.

Lontoh, S. \& Semrau, J. D. (1998). Methane and trichloroethylene degradation by Methylosinus trichosporium OB3b expressing particulate methane monooxygenase. Appl Environ Microbiol 64, 1106-1114.
McCarthy, A. J. \& Williams, S. T. (1992). Actinomycetes as agents of biodegradation in the environment - a review. Gene 115, 189-192.

Mohr, T. K. G. (2001). Solvent Stabilizers. San Jose, CA: Santa Clara Valley Water District.

Parales, R. E., Adamus, J. E., White, N. \& May, H. D. (1994), Degradation of 1,4-dioxane by an actinomycete in pure culture. Appl Environ Microbiol 60, 4527-4530.

Pasti-Grigsby, M. B., Lewis, T. A., Crawford, D. L. \& Crawford, R. L. (1996). Transformation of 2,4,6-trinitrotoluene (TNT) by actinomycetes isolated from TNT-contaminated and uncontaminated environments. Appl Environ Microbiol 62, 1120-1123.

Reichert, K., Lipski, A., Pradella, S., Stackebrandt, E. \& Altendorf, K. (1998). Pseudonocardia asaccharolytica sp. nov. and Pseudonocardia sulfidoxydans sp. nov., two new dimethyl disulfide-degrading actinomycetes and emended description of the genus Pseudonocardia. Int J Syst Bacteriol 48, 441-449.

Rhuland, L. E., Work, E., Denman, R. F. \& Hoare, D. S. (1955). The behavior of the isomers of $\alpha, \varepsilon$-diaminopimelic acid on paper chromatograms. J Am Chem Soc 77, 4844-4846.

Richardson, R. E., Bhupathiraju, V. K., Song, D. L., Goulet, T. A. \& Alvarez-Cohen, L. (2002). Phylogenetic characterization of microbial communities that reductively dechlorinate TCE based upon a combination of molecular techniques. Environ Sci Technol 36, 2652-2662.

Saitou, N. \& Nei, M. (1987). The neighbor-joining method: a new method for reconstructing phylogenetic trees. Mol Biol Evol 4, 406-425.

Tanner, R. S. (1997). Cultivation of bacteria and fungi. In Manual of Environmental Microbiology, pp. 52-62. Edited by C. J. Hurst, A. R. Knudsen, M. J. McInerney, L. D. Stetzenbach \& M. V. Waller. Washington, DC: American Society for Microbiology.

Wackett, L. P., Brusseau, G. A., Householder, S. R. \& Hanson, R. S. (1989). Survey of microbial oxygenases: trichloroethylene degradation by propane-oxidizing bacteria. Appl Environ Microbiol 55, 2960-2964.

Warwick, S., Bowen, T., McVeigh, H. \& Embley, T. M. (1994). A phylogenetic analysis of the family Pseudonocardiaceae and the genera Actinokineospora and Saccharothrix with 16S rRNA sequences and a proposal to combine the genera Amycolata and Pseudonocardia in an emended genus Pseudonocardia. Int J Syst Bacteriol 44, 293-299.

White, D. C. \& Ringelberg, D. B. (1998). Signature lipids biomarker analysis. In Techniques in Microbial Ecology, pp. 255-272. Edited by R. S. Burlage, R. Atlas, D. Stahl, G. Geesey \& G. Sayler. New York: Oxford University Press.

Zhou, W. \& Zimmermann, W. (1993). Decolorization of industrial effluents containing reactive dyes by actinomycetes. FEMS Microbiol Lett 107, 157-161. 